Matjaž Celarc

\title{
Teološki pogled na spolne zlorabe v Cerkvi: teološki razmislek (2.del)
}

\section{Theological Perspective on Sexual Abuse in the Church: Theological Reflection (Part 2)}

Poværetek: Članek nadaljuje prejšnji prispevek občutljive problematike spolnih zlorab otrok v Cerkvi. Prvi del je orisal splošni pregled tematike, v drugem delu pa bo na podlagi pridobljenega znanja in vprašanj prvega dela v ospredju teološki razmislek. Članek na svetopisemski podlagi ovrednoti podobo Boga in dostojanstvo otroka in žene. Ključni poudarek je spodbuda k medsebojnemu poslušanju, ki omogoča soočenje z resnico in odpuščanje in spravo. Zaporedje dveh člankov se sklene s povabilom k celoviti spreobrnitvi srca in k odpuščanju kot temelju za zdravljenje in obnovo.

Ključne besede: Cerkev, spolna zloraba, formacija, duhovniški celibat

Abstract: The article continues the contribution of a general overview of the delicate topic of child sexual abuse in the Church. Based on the acquired knowledge and questions of the first, the second article wants to make a theological reflection Therefore, the article evaluates the image of God and the dignity of the child and the woman on a biblical basis. The key focus is the encouragement to reciprocal listening, which enables a confrontation with the truth, forgiveness and reconciliation. Thus, the article concludes the sequence of two articles with an invitation to a complete conversion of the heart and to forgiveness as the basis for healing and recovery.

Keywords: Church, sexual abuse, formation, priestly celibacy

\section{Iskanje teološkega odgovora}

V prvem članku smo se soočili z definicijami in splošnimi okviri problematike zlorab v Cerkvi. Prebiranje študij Keenanove, Cahilla in Wilkensona ter poročil z različnih koncev sveta in zgodb osebnih pričevanj je človeka na eni strani pretreslo, po drugi strani pa so se kot pomenljivi izkazali nekateri pomisleki in predlogi teh 
študij, predvsem v smeri teološkega razmisleka. Prav zato bomo v tem članku razmišljali o nekaterih teoloških podobah in področjih, ki so se pri zlorabah pokazali kot napačno razumljeni ali celo zlorabljeni. Izpostavili bomo podobo Boga, dojemanje otroka in ženske in ne nazadnje razumevanje občestva vere in življenja, ki je bilo ranjeno in potrebuje korake očiščenja in ozdravljenja. Za vsebinski temelj temu razmisleku bomo uporabili Sveto pismo, ki kot božja Beseda človeku pomaga na poti $\mathrm{k}$ resnici in življenju.

\subsection{Podoba Boga in teološka nerazumevanja}

Raziskava Cahilla in Wilkensona se opre na Ransona (1997), ki ugotavlja, da se pri dojemanju Boga in razmerij srečujeta dve prvini: helenistična podoba očeta, ki je ,pater familias', in biblična podoba Boga Očeta, vendar je skozi zgodovinski razvoj Cerkve in klerikalno-hierarhične ureditve prva podoba dobila prednost $(2017,214)$. $\mathrm{V}$ tem oziru storilec, ki Boga dojema kot vsevidnega sodnika, najde opravičilo in preložitev svoje odgovornosti, saj je Bog tisti, ki izbira za službo, in tisti, ki bi zmogel to preprečiti. Poleg tega pa hierahično dojemanje Boga pripomore k idealizaciji vloge duhovnika, ki v očeh ljudi postane nezmotni, popolni in nedotakljivi posrednik Boga. Vendar je treba ob tem razumeti ne le človeško dimenzijo, temveč tudi teološko postavko, da je duhovnik kot alter Christus. Duhovnik, ki s posvečenjem prejme zakramentalni karakter, je ontološko spremenjen, vendar ob tem ni postavljen na piedestal božanstva in ni ponovitev hipostatične unije, temveč je maziljen, da v skupnosti v Jezusovem imenu in po njegovem zgledu živi vloga pastirja (Jn 10,14-15). To ni zgolj službena funkcija, temveč celotno duhovnikovo življenje, ki je pred Bogom in Cerkvijo prežeto z ljubeznijo in odgovornostjo za ljudi. Duhovnik živi v razpetosti med svojo duhovniško vlogo, ko po prejemu zakramenta svetega reda ljudem prinaša Kristusa, in svojo vlogo vernika, ko se prepoznava kot šibkega človeka, ki je prav v tem prvi prejemnik božje ljubezni. Duhovnik svoje življenje lahko prepoznava $v$ besedah apostola Pavla, ko pravi:

»Ne živim več jaz, ampak Kristus živi v meni. Kolikor pa zdaj živim v mesu, živim v veri v božjega Sina, ki me je vzljubil in daroval zame sam sebe." (Gal 2,20)

Podobno napačna podoba Boga vpliva na razumevanje greha in spovedne prakse. Greh je tako razumljen zgolj kot individualni prekršek pred Bogom sodnikom, kateremu pri spovedi izraziš svojo napako in prejmeš odpuščanje. Študije (npr. Keenanina) razmišljajo o problemu tovrstnega dojemanju spovedi kot cenene milosti odpuščanja spovedancu in nemoči reagiranja zaradi spovedne molčečnosti na ravni spovednika. Spoved ni toliko prostorje odpuščanja in rasti kakor varni prostor odpiranja nerazrešenih težav. (Keenan 2012) Iz tega naslova nekatere študije in tudi avstralsko poročilo priporočajo deabsolutizacijo oziroma umik spovednega pečata v tako hudih kriminalnih primerih ogrožanja človeškega življenja. Spovedno prostorje ni skrivalnica, temveč intimni prostor pred Bogom, kjer človek kot posameznik izpove svoj greh in se odloči za poboljšanje. Spovedanec izpoveduje necelostnost, nezvestobo in lažno ljubezen in prosi za prenovljenje: „Čisto srce, o Bog, mi ustvari, stanovitnega duha obnovi v moji notranjo- 
sti. « (Ps 51,12) Kakor se vsaka prenova začne z iskreno izpovedjo, ta izpoved ostane neučinkovita, če ne zadeva celote življenja spovedanca. Bog je tu razumljen kot usmiljeni oče, ki naredi vse, da bi vsak njegov rojenec prišel k življenju in v resnici vstopil v veselje očetove hiše. (Lk 15,31-32)

\subsubsection{Svetopisemska podoba Boga kot očeta}

Zgoraj omenjene študije vabijo k osvetlitvi svetopisemske podobe Boga Očeta, to pa ima za posledico ne zgolj odvrnitev od napačnega teološkega razumevanja, temveč tudi bolj celostno doumevanje duhovništva v luči zaveze z Bogom in z ljudmi.

Podoba očeta ima v Svetem pismu poseben pomen, zlasti ko je vezana na obljubo božjega blagoslova, kakor to srečamo pri odnosu med Abrahamom in Izakom (1 Mz 22,7-8), ali na družinsko vzgojo modrosti in postave ( $\operatorname{Prg} 1,8)$. Podoba Boga kot očeta je v Stari zavezi resda redkeje navzoča, vendar jo najdemo pri prerokih kot znamenje zaveze med Bogom in njegovim ljudstvom, kot znamenje božje skrbi in zvestobe v odnosu do ubogih in šibkih. Podoba Boga očeta zarisuje stvarnika (Iz 64,7) in rešitelja (Iz 63,16; Oz 11,1), ki je materinsko skrben in zvest (Iz 49,14-16) in obenem odgovoren za sedanji trenutek božjega ljudstva in vsega človeštva (Iz 63,15-64,11).

Nedvomno pa podoba Boga kot Očeta stopi v ospredje z Jezusom, ki z Bogom oblikuje poseben, sinovski odnos (Lk 10,21-22) in tega odnosa uči svoje učence $(11,1-2)$. Jezus vabi k nenehnemu poglabljanju intimnega odnosa z Očetom kot svojim roditeljem. Morda je najlepši prikaz Boga kot očeta prilika o usmiljenem očetu (15,11-32). Oče, ki za oba svoja sinova stori vse, dopušča svobodno odločitev tako pri zapuščanju kakor tudi pri vračanju in vstopanju v veselje očetove hiše. Pri tem ne govorimo o ceneni rešitvi: na eni strani mlajši sin skorajda umre in nosi brazgotine poti, na drugi strani pa starejši sin ostaja nesvoboden kljub trdnosti doma. Cena rešitve in novega življenja je iskrenost do sebe in do drugih: priznanje svojih napak in odločitev za vstop v očetovo hišo. Sinovski odnos z Očetom naj bi spreminjal pogled na življenje in na medsebojne odnose $(15,31)$. Novo življenje in prenovljeni odnos z Bogom se prejemata z duhom posinovljenja, v katerem kličemo: »Aba, Oče!« (Rim 8,15; Gal 4,6)

\subsubsection{Bog kot Oče zaveze}

Sveto pismo poudari, da je Bog bitje odnosa (1 Mz 1,26), ne zaradi neke nujnosti ali potrebe (prim. $2 \mathrm{Mkb} 7,23.28$ ), temveč iz svobodne notranje odločitve za darovanjsko ljubezen. Bog nima potrebe in si ne želi delati imena, kakor to dela človek $(1 \mathrm{Mz} 11,4)$. Nasprotno, Bog daje ime skupaj s poslanstvom za rešenje skupnosti ( $2 \mathrm{Mz} 31,2$; Iz 43,1) in za oblikovanje občestva (1 Jn 1,3), to pa pomeni deliti božje življenje $(17,20-23)$.

V kontekstu temeljne zaveze med Bogom in božjim ljudstvom (2 Mz 19-20) najdemo tudi izraze kakor lastninsko ljudstvo, posvetiti, vzdržnost v čistosti, ki pomagajo vrednotiti in bolje razumeti celibat, boguposvečenost. Čeprav se starozavezni duhovniki bistveno razlikujejo od novozaveznega velikega duhovnika Jezusa - ki ne opravlja le daritve zase in za druge, temveč sam postaja večna, nedolžna daritev za naše odrešenje (prim. Hebr 5,1-10; 7,22-28) -, so starozavezni duhovniki skupaj z vsem ljudstvom po- 
vabljeni, da se posvetijo ( $2 \mathrm{Mz} 19,22$ ), to pomeni, da se očistijo, operejo svoja oblačila $(19,10)$, se vzdržijo spolnosti, se torej ne bližajo ženi $(19,15)$, in ne pritiskajo, ne izsiljujejo ali izrabljajo skrivnosti in svetosti Bogu izvzetega kraja $(19,24)$. Duhovniki so torej predstavniki ljudstva, ki naj bi kot zgled vsemu ljudstvu zase in za ljudstvo opravljali daritve Bogu. Govor o svetosti in kraljestvu duhovnikov je navzoč v kontekstu zaveze, ki jo Bog želi skleniti z ljudstvom:

"Sami ste videli, kaj sem storil Egipčanom in kako sem vas nosil na orljih perutih in vas pripeljal k sebi. Zdaj pa, če boste res poslušali moj glas in izpolnjevali mojo zavezo, mi boste posebna lastnina izmed vseh ljudstev, kajti moja je vsa zemlja. Vi mi boste kraljestvo duhovnikov in svet narod." (2 Mz 19,4-6)

Bog najprej obuja spomin na to, kar so že sami izkusili in videli; na rešenje namreč, na osvoboditev; lahkotnost prihaja le od Gospoda. Bistveni poudarek božjega nagovora pa pomeni vabilo k poslušanju in izpolnjevanju zaveze. To je pogoj, da ljudstvo postane posebna božja lastnina. Če ob tem razmišljamo o duhovništvu, o boguposvečenosti in o celibatu kot o posebnem odnosu z Bogom, je treba poudariti, da pri tem ne govorimo o suženjske, razmerju, temveč o mistični, intimni bivanjski povezanosti, ki naj bi dušo, celotno življenje duhovnika, povezala z Bogom do tolikšne mere, da odmeva spev Visoke pesmi: »Moj ljubi je moj in jaz sem njegova." (Vp 2,16) To mistično razumevanje odnosa z Bogom pomeni podaritev svojega življenja Bogu, to pa se more zgoditi le ob poslušanju in življenju iz tega odnosa. Poslušanje namreč pomeni, izstopiti iz sebe in stopiti v svet drugega, to je: stopiti z njim v odnos, posledica pa je, da sebe in svet okrog sebe vidimo drugače. Iz tega lahko sledi življenje iz zaveze, ki v prvi vrsti ne pomeni izpolnjevanja predpisov, temveč izpraznitev sebe v poslušnem zaupanju Bogu, kakor to stori Kristus (Flp 2,6-8), ki pa nikdar ne ostaja osamljen, saj je Oče z njim (Jn 16,32). Življenje iz zaveze pomeni, da je duhovnik sprejel ljubezen in je sposoben ljubezen s svojim življenjem podariti naprej (15,8-10).

\subsubsection{Bog kot Oče družine vernikov}

Jezus oblikuje identiteto svoje skupnosti kot božjo družino z vzorom molitve (Lk $11,1-13)$ ter poslušanja in izpolnjevanja božje besede $(8,21)$. Bratstvo v božji družini presega zemeljske vezi. Če so te vezi ponekod okrnjene in omejene zgolj na ugodnostih $(14,26)$, naj bi bratje božje družine delili veselje Očeta nad življenjem in rešenjem slehernega $(15,32)$, to pa pomeni tudi, naj bi si pomagali med seboj in nosili bremena drug drugemu (Gal 6,2). $V$ takšnem dojemanju naj bi se tudi med duhovniki izoblikovali povezanost in zaupanje, ki ublažita izziv osamljenosti in težo sprejemanja odločitev v pastirski službi. Jezus skupnost učencev opozarja na nevarnost iskanja zunanjih časti in spodbuja k celostni drži služenja in sodelovanja kakor med brati ene družine:

"Vi pa si ne pravite ,rabi', kajti eden je vaš Učitelj, vi vsi pa ste bratje. Tudi na zemlji nikomur ne pravite ,oče', kajti eden je vaš Oče, ta, ki je v nebesih. 
Tudi si ne pravite ,vodnik', kajti eden je vaš Vodnik, Mesija. Največji med vami bodi vaš strežnik. Kdor se bo poviševal, bo ponižan, in kdor se bo poniževal, bo povišan.« (Mt 23,8-12)

Z občestveno miselnostjo duhovnik sebe vidi razbremenjenega in povezanega s celoto, tako znotraj duhovniške skupnosti kakor tudi skupnosti, kateri je postavljen kot pastir. Takšno dojemanje duhovniškega bratstva ni v spotiko (Rim 14,13), temveč v oporo pri darovanju za druge $(12,1-10)$ in pri graditvi Kristusovega telesa $(1$ Kor 12,1). Pod tem svetopisemskim pogledom postane razvidno, da podoba Boga Očeta razodeva božjo skrb za polnost življenja prek iskrenosti in tudi vzgoje. To postaja vodilo za vernike, toliko bolj za oznanjevalce evangelija, ki so povabljeni, da svojo izkušnjo občestva z Bogom živijo najprej med seboj in jo nato prinašajo med ljudi.

\subsection{Teologija otroka}

Študije izpostavijo problematiko splošnega dojemanja otrok tako v družbenem kontekstu kakor tudi v sklopu Svetega pisma. Zaničevalni pogled na otroke ustvarja okolje, ki omogoča instrumentalizacijo in zlorabo otrok na več ravneh. Že papež Janez Pavel II. je v nagovoru ameriškim kardinalom dne 23. aprila 2002 dejal: „V duhovništvu in redovništvu ni prostora za tiste, ki bi otrokom storili kaj žalega." Sveto pismo odseva bolj negativen pogled na otroka, ki je vladal v tedanji družbi, vendar pa s paleto prekrivajočih se izrazov nakazuje, da otrok in mlad človek nista vnemar za svetopisemsko misel, zlasti ko izpostavimo Jezusov ali Pavlov pogled.

\subsubsection{Otrok in mladenič}

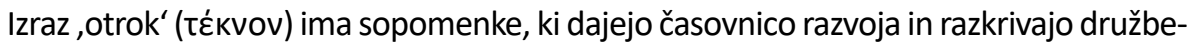
na razmerja, po katerih je nedorasli otrok poimenovan kot ,suženj, služabnik, otrok' ( $\pi \alpha \tilde{c} \varsigma, \pi \alpha \tilde{\varsigma} \varsigma$ ), torej potreben vzgoje in rasti, da resnično postane sin in dedič (Gal 3,2429). Za vzgojo lahko poskrbijo pedagogi, izobraženi sužnji, ki pomagajo k napredovanju v znanju in modrosti, zato nas ne preseneti, da najdemo paleto izrazov, ki nakazujejo starostno razlikovanje:

- ,otročič, majhen otrok' do sedmega leta starosti: raıઠíov (1 Mz 17,12);

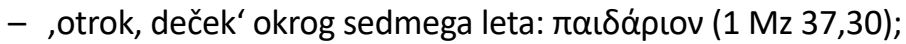

- ,deček' med sedmim in štirinajstim letom starosti: $\pi \alpha \tilde{c} \varsigma(1 \mathrm{Mz} 12,16)$ in veavíбко (1 Mz 4,23);

- ,mladenič, mlad fant': veavias (Sod 17,7);

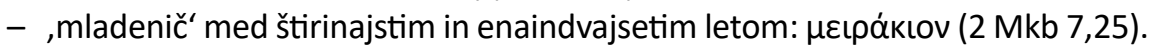

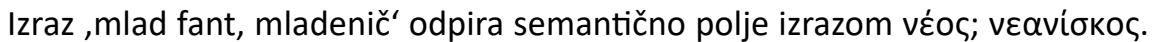
$\checkmark$ svetopisemskem okviru je dojemanje ,mladega, mlajšega, mladostnega“ ambivalentno. Kulturno ima prvenstvo starejši, vendar pa starejši ni vedno modrejši, lahko zapelje in je zato vladanje mlajšega bolj smiselno, saj ni pokvarjen oziroma skrbi za dom kakor Jakob (1 Mz 27,15: Ezav in Jakob) ali Benjamin (1 Mz 42,15). 


\subsubsection{Jezusov in Pavlov odnos}

Jezus nedvomno postavlja drugačne norme, saj sprejema in blagoslavlja otroke in jih postavlja za merilo kraljestva (prim. Mt 19,14). Jezus pri tem ne misli na otročjo držo - saj jo kot nezrelost in nerazpoložljivost srca ne glede na leta kritizira $(11,16$ 17) -, temveč misli na otroško nepokvarjenost, preprostost in zaupljivost, ki se ne napihujejo z vedenjem, temveč se predajajo modrosti Očetovega razodetja (prim. Lk 10,21). Tako Jezus sam raste kot otrok in mladostnik $(2,40.48-49)$ in se identificira z malimi, ko pravi: »Kdor sprejme tega otroka v mojem imenu, mene sprejme, in kdor mene sprejme, sprejme tistega, ki me je poslal. « $(9,48)$ Obenem pa ga prav otroci prepoznavajo kot pravega kralja (Mt 21,15). Podobno Pavel pojmuje kot svoje duhovne otroke spremljevalce, denimo Timoteja $(1 \mathrm{Kor} 4,17)$ in tudi člane svoje skupnosti (1 Kor 4,14; 2 Kor 6,13). Poudarek je seveda na ravni vzgoje (1 Tim 5,4), ki pa ne sme greniti (Kol 3,21), temveč mora imeti za merilo Gospodovo vzgojo $(E f 6,4)$. Pri vsem tem ni pomembno izničenje razlik, saj otroci morajo iti skozi vzgojo, temveč nujnost spoštljive vzgoje, saj sta njihova iskrenost in preprostost znamenje božjega kraljestva. Morda je pomembno spoznanje, vendar ne kot vedenje, s katerim bi prezirali, temveč spoznanje iz ljubezni, ki uvidi in sprejme svojo odgovornost (Lk 12,48) in je obzirno do šibkejšega. (1 Kor 8,1-3)

\subsubsection{Mladoletni kot božji izvoljenec}

Kakor papež Frančišek v knjigi Bog je mlad razmišlja, da nas mladi prosijo, naj jim prisluhnemo, pomagamo in jih ne izkoriščamo $(2018,19)$, tako prav starozavezna tradicija postavlja pred nas mladoletne, ki dvignejo svoj glas in sredi preizkušnje postanejo znanilci božje moči. Nagovori nas zgled sedmih bratov in njihove matere, ki doživijo mučenje v obdobju kralja Antioha (2 Mkb 7,1-41). Ob smrti najmlajšega njegova mati spregovori o moči Boga Stvarnika in o življenju po smrti, to pa presega vsako rabljevo dejanje (1 Mkb 7,28-29). Podobno zgodba o Danielu pričuje o mladeničih v času babilonskega kralja Nebukadnezarja, ki ne podleže pritiskom in vztraja v veri in si pridobi modrost (Dan 1,1-21). Enako mladeniči, ki nočejo častiti malika, postanejo kamen spotike in so vrženi v ogenj, vendar so tam po angelu čudežno rešeni, da postanejo priče resničnega Boga (Dan 13,1-30). Podobno vidimo mladeniča Daniela v Suzanini zgodbi, ko Bog obudi Svetega Duha v mladem dečku, da vpije: "Čist sem pri krvi te žene." $(13,46)$ Mladi deček ima modrost, $s$ katero razbere resnico zlorabe moči, ki sta jo hotela izrabiti do mere smrti svoje žrtve dva Izraelova sodnika, pa sta si tako sama nastavila past sodne obravnave $(13,49-64)$. Skupni imenovalci zgodb so vera, zaupanje v Boga in resnica. To daje moč vztrajanja v preizkušnji, še več, pripomore celo $k$ spreobrnjenju in rešitvi nedolžnega življenja. Čeprav se zdi, da Sveto pismo dojema otroke kot nezrele in nedorasle za življenje, pa je večkrat razvidno, da sta prav otrok in mlad človek lahko s svojo preprostostjo znanilca odrešenja in božjega kraljestva. Otrok in mladostnik se morata učiti za življenje od odraslih, zato ju je treba na eni strani varovati kakor punčico svojega očesa (prim. $5 \mathrm{Mz} 32,10$ ), na drugi pa spoštovati in se od njiju tudi učiti. 


\subsection{Teološka antropologija in odnos do žensk}

Z odpiranjem teološke misli ob problemu spolnih zlorab je postalo razvidno, da to ni toliko problem celibata kakor pa degradacije zdravega družinskega okolja, v katerem so razmerja in odnosi disfunkcionalni oziroma je dostojanstvo oseb in življenja postavljeno pod vprašaj (Carola, Rotsaert et al. 2012, 121-125) Poleg tega negativni odnos do žensk in ženskega sveta razodeva nerazumevanje teologije stvarjenja, to je: različnosti in komplementarnosti med moškim in žensko, ki naj bi sooblikovala življenje in si med seboj pomagala. Človek je ustvarjen za odnos in ljubezen kot podaritev, kot preseganje osamljenosti in egoizma. Prav zatekanje $k$ Svetemu pismu pokaže resnično dostojanstvo žene in božje usmiljenje, potrebno za ozdravljenje in prenovo.

\subsubsection{Stvarjenje in dostojanstvo žene}

Stvarjenje pomeni prvo dejanje za vzpostavitev zaveze s človekom. Zavezo je mogoče razumeti kot vez prijateljstva, a obenem tudi kot pravni akt, pogodbo, ki določa odgovornosti, privilegije in obveznosti obeh strank v odnosu. Kadar je eden od partnerjev zaveze Bog, mora Bog prevzeti večjo odgovornost za realizacijo zaveze. Člo-

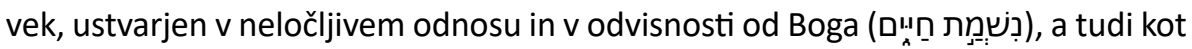

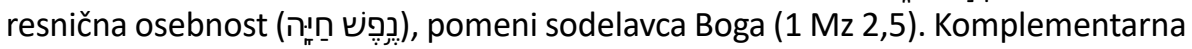
raznolikost človeštva, občestvo moškega in ženske, odseva podobo Boga $(1 \mathrm{Mz}$ $1,27)$ in svojo odgovornost ob »kosti mojih kosti in mesu mojega mesa $(2,23)$.

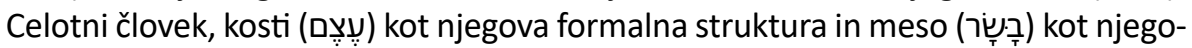
va krhkost, je oblikovan kot občestvo moškega in ženske, z enakim dostojanstvom in odgovornostjo drug do drugega in do stvarstva.

Kadar človek ne posluša Boga, ampak zgolj svoje meso in kosti, se harmonija odnosov zruši in rodita se zaničevanje in očitanje $(3,11-13)$. Negativna podoba žene je večkrat izpostavljena. Ni le izpostavljeno družbeno okolje žrtvovanja otrok in deklet (Sod 11,29-40), božje ljudstvo samo je namreč predstavljeno kot hotnica (Ezk 16,2022). Dostojanstvo žena potrjujejo žene, ki se pogumno in borbeno postavijo za uničenje sovražnikov ljudstva (Sod 4,1-24; Jud 13,1-10; EstG 7,1-10) s pravičnostjo in krepostjo, s katerima žena, denimo Suzana, presega sodnike ljudstva (Dan 13,1-64).

\subsubsection{Dostojanstvo moža in žene v Kristusu}

Rodovnik Jezusa Kristusa izpostavi, kako Bog za odrešenje svojega ljudstva vplete prav žene (Mt 1,1-17). V tem načrtu ima posebno mesto Marija, ki je devica, dekla Gospodova in obdana z močjo Najvišjega (Lk 1,26-38). Marija, ki v polnosti časov daje življenje božjemu Sinu, v polnosti deli tudi njegovo življenje (prim. Gal 4,4). Porušeno izhodiščno ravnovesje med možem in ženo se prav po Mariji uresničuje z obljubo odrešenja $(1 \mathrm{Mz} 3,15)$. Tako človekovo življenje prejme novo dostojanstvo v srečanju s Kristusom (Flp 1,21), v njegovem Duhu (Rim 8,15-17) in v skrivnosti Kristusa in njegove Cerkve (Ef 5,21-28).

Kristus sprejema in rešuje žene, denimo vdovo iz Naina (Lk 7,11-17), skrušeno grešnico, ki ji odpusti grehe (7,36-50), in ne nazadnje bolne in preizkušene, ki mu 
strežejo $(8,1-3)$. Jezus prijateljuje z ženami $(10,38-42)$ in prav žene spremljajo njegove poslednje trenutke (Lk 23,49; 24,1-11). Prav vsem velja dostojanstvo v Kristusu (1 Kor 11,11), žene pa so obenem ključne za rast skupnosti (Apd 16,11-15), čeprav se zdi, da ne opravljajo vodstvenih služb, saj Pavel pravi, naj bi v skupnosti molčale (1 Kor 14,34-35). Imajo mesto strežbe in služenja v ljubezni kot diakonise (Rim 16,1) ali vdove (1 Tim 5,3-16), imajo posebno vlogo žene in matere v skladu z ljubeznijo in spoštovanjem v Kristusu (Kol 3,18-20). Človekovo dostojanstvo se najde $v$ komplementarnosti med moškim in žensko. Kljub različnim biološkim in osebnostnim danostim imata oba enako dostojanstvo v Kristusu. To je temeljno izhodišče vsakega služenja in podrejanja drug drugemu iz ljubezni in spoštovanja. Čeprav nimata enake vloge v Cerkvi, je temeljno ne le sprejetje svoje vloge, temveč tudi spoštovanje vloge vsakega.

\subsubsection{Davidov greh za spoznanje in rast}

Če bi v svetopisemskem okviru želeli izpostaviti paradigmatični greh zlorabe moči, vpliva in spolnosti, je Davidov greh idealen zgled, saj prikaže, da lahko kralj, čeprav božji maziljenec, zanemari svoje dolžnosti in se lenobno preda brezdelju ter v več korakih zlorabi svojo moč in položaj. Lahko bi rekli: greh rodi greh. Poigravanje s spolnim poželenjem prek poizvedovanja preide $v$ spolno dejanje in spočetje novega življenja. Želja po zakritju dejanja rodi domiselno spletko, da pod pretvezo poizvedovanja o bitki Urija privedejo domov iz bitke in ga prepričajo, da poišče svojo ženo Batšebo in mu je tako pripisano očetovstvo. Spletka se ne uresniči, temveč vodi v nov greh: v načrtovan umor Urija in prevzem njegove žene. Greh ni prikrit božjim očem. Bog po preroku Natanu Davidu prikaže njegov greh (2 Sam 12), ki bo imel posledice za celotno njegovo hišo, greh spolne zlorabe se bo dogajal pred Davidovimi očmi (12,11-12). David pa prizna svoj greh in je deležen božjega odpuščanja, toda posledica bo smrt njegovega sina (12,13-14). $V$ ta trenutek svetopisemska tradicija postavi psalm 51, v katerem David izpoveduje greh in prosi za odpuščanje in za veselje odrešenja (Ps 51,7-14). David, ki ne želi borbe z uporniki, temveč učenja pravičnosti in božje hvale, sam v daritev Bogu daje potrtega duha, saj le Bog lahko obnovi porušeno in si napravi primerno daritev (Ps 51,15-21). David se ob svojem grehu uči, kaj pomeni spoštovanje žene, spolnosti in zakona, o tem spregovori Pavel (Ef 5,21-28), in kaj pomeni resnična oblast, o tem govori Kristus (Mt 10,42-45). Padci bolijo, vendar pokažejo tudi pomanjkljivosti naših predstav, okolij in sistemov. Obenem pa prav padci pomagajo izoblikovati strukture zaščite in pripomorejo k celostni rasti. Človek je ustvarjen kot bitje odnosa; $v$ različnosti in $v$ komplementarnem dopolnjevanju moškega in ženske. S tem zavedanjem je mogoče vzpostavljati zdrave, zrele in odrešujoče odnose, ki zmorejo v družino, Cerkev in širšo skupnosti prinašati življenje.

\subsection{Teologija občestva in možnost sprave}

Problematika presega okvire pred- in pokoncilske ekleziološke debate, vendar pa je, podobno kakor ob zgoraj navedenem pogledu na otroka in na žensko, treba tudi ekleziološki okvir očistiti pretirane idealizacije (divinizacije) duhovnikov, ki vodi tako 
glede klerikov kakor tudi glede laikov v škodljivo klerikalizacijo. Če je investiturni boj v visokem srednjem veku botroval razvoju klerikalne avtonomije in pravni zasnovi dveh razredov kristjanov, klerikov in laikov, in se je z razvojem protestantizma ta diskrepanca poglabljala, se je skozi stoletja zgodil preobrat v bolj svetopisemskem dojemanju skupnosti, v bolj občestvenem dojemanju. Skupnost kristjanov je razumljena kot ena sama celota, kot občestvo prijateljev oziroma kot družina (Apd 4,32), kot božje ljudstvo (1 Pt 2,10) in Kristusovo telo (1 Kor 12,12-27). Znotraj te perspektive so še vedno navzoči greh (Apd 5,1-11), boj za moč (Lk 22,24-30; Gal 2,1-14) in prepir (1 Kor 1,10-17), vendar je vodilna logika prežeta z modrostjo križa $(1,17)$, ki sočutno gleda na trpljenje enega dela telesa kot na trpljenje celote $(12,26)$. Tovrstno dojemanje temelji na Jezusovem zgledu služenja (Mr 10,45) in na čutenju (Flp 2,1-4). Tako je skupnost povabljena, da na podlagi različnosti situacij in ogroženosti izbira med potjo sprejemanja krivice (1 Kor 6,1-11) in potjo soočenja s tistim, ki dela krivico, ter z opozorilom na greh v več korakih: na štiri oči, znotraj kroga prijateljev, znotraj celotne skupnosti in tudi do tiste mere, ko je treba uporabiti zdravilno izključitev zaradi spreobrnjenja (Mt 18,15-17).

\subsubsection{Možnost sprave}

Vse to govori o rani pohujšanja malih in vse celote Cerkve (Mt 18,6). Vsako izmikanje in nesoočanje s situacijo je to rano poglabljalo. Vsaka misel na ceneno milost je ceno ozdravljenja višala. Kakor Peter in Juda Iškarijot različno odgovorita na svoje izdajstvo (Lk 22,62; Apd 1,18), tako ima Cerkev kot skupnost različne možnosti. Jezus jo vabi na pot resnice, na pot besede in življenja, ki edina osvobaja (Jn 8,31-36) in vodi k spoznanju božje ljubezni (Jn 3,16). Sprava in odpuščanje nista nekaj cenenega, temveč imata vedno visoko ceno (1 Pt 1,18-19), ki ne more iti mimo križa in odpuščanja, to pa je znamenje božje ljubezni za vse ljudi $(J n$ 3,16). Cerkev je povabljena k poslušanju, k razločevanju, k molitvi za odpuščanje in spravo. Pri tem so pomembni delo v duhovniški formaciji, celostna formacija in spremljanje, pa tudi iskanje sprave in ozdravljenje ran.

Vzpostavitev pravičnosti je seveda božje delo, vendar je človeški dejavnik še kako pomemben. Pri razmišljanju o pravičnosti, spravi in odpuščanju ne želimo v polnem smislu vstopiti na področje sodnega prava in sodnih obravnav (Kongregacija za nauk vere 2020), temveč ovrednotiti svetopisemski model obnove pravičnosti med dvema strankama, kakor lepo prikaže študija Pietra Bovatija Ristabilire la giustizia (2005). V bistvu govorimo o dveh možnostih vzpostavitve pravičnosti in sprave:

- sodna obravnava (מְְְִפָּט) s končno razsodbo in obsodbo;

- ,pravdanje‘ (ריב), ki je soočenje z iskanjem resnice in spreobrnjenja.

Za naš okvir je morda smiselno ovrednotiti temeljne postavke pravdanja (postopka mediacije, ki je pred sodnim procesom): soočenje med dvema strankama v zavezi, ko prizadeta stran predstavi situacijo in greh storilca, ne zaradi končne obsodbe, temveč za spreobrnjenje in ponovno vzpostavitev pravičnosti in zaveze. Lep zgled tovrstne pravde, h kateri Bog poziva svoje ljudstvo, najdemo pri preroku Izaiju, ko daje slišati božji glas: 


\begin{abstract}
»Pridite, pravdajmo se, govori GOSPOD:
Če so vaši grehi rdeči kakor škrlat, bodo beli kakor sneg,

če so rdeči kakor bagrenina, bodo beli kakor volna.

Če me boste radi poslušali, boste uživali dobrine dežele.

Če pa nočete in se upirate, vas meč požre, kajti GOSPODOVA usta so

govorila.« (Iz 1,18-20)
\end{abstract}

Bog kot partner zaveze višjega ranga ima v tem odnosu večjo odgovornost in tako tudi nalogo, da poskuša ponovno vzpostaviti pravo in pravično razmerje. Pri tem gredo $z$ roko $v$ roki prikaz greha, ki je porušil odnos zaveze, ter poslušanje očitka in sprejemanje posledic, to pa omogoči, da se zopet vzpostavi blagoslov. Tu želimo izpostaviti nekaj elementov te pravde in soočiti vse skupaj s problematiko zlorab.

\title{
Predstavitev greha
}

Tu sta nedvomno v igri vera in morala: dojemanje Boga in sebe. Strah pred kaznijo odpre začarani krog nezaupanja in fragmentiranje osebnosti. Veliko storilcev je trpelo zaradi nizke samopodobe in dvomov spolne usmerjenosti, vendar je vse to ostalo skrito, potlačeno. Udarilo je ven kot ločevanje med privatno osebo in službeno funkcijo. $V$ tem okviru se zgodi zloraba, ki prav tako ostane neprepoznana, zanikana, potlačena in opravičevana.

\section{Poslušanje žrtve}

Soočenje s svojo bolečino, $s$ strahom in občutkom krivde, je pred nadaljnjimi koraki. Ena od temeljnih postavk je prav raven poslušanja: biti slišan, razumljen in ne vnovič zlorabljen. Poslušanje je pomemben dejavnik k ozdravljenju, saj pomaga žrtvi izstopiti iz ujetosti odnosa s svojim rabljem in narediti nov korak. To se lahko zgodi prek prijateljev, najpogosteje prek intimnega odnosa, ki pripomore, da se odprejo stare rane, vendar se lahko v odnosu tudi zdravijo.

\section{Zadostilni dar}

Zadostilni dar ni odplačilo, saj denar ne more ozdraviti rane. Storilec lahko naredi korak s poslušanjem, s sprejemanjem odgovornosti za svoja dejanja, to pa ga vodi $k$ skrušenosti, $k$ priznanju krivde in teže njegovih dejanj, $k$ molitvi za odpuščanje in $\mathrm{k}$ terapevtskemu delu za soočenje $\mathrm{z}$ njegovo psihoseksualno resničnostjo. Včasih je potrebna izključitev (oče mora zadati tudi primerno kazen in ne vstopati $v$ ceneno usmiljenje in proces manipulativne logike soodvisništva).

\section{Odpuščanje kot pot ozdravljenja in sprave}

Žrtev oziroma preživeli potrebuje odkritje preseganja samega sebe oziroma odkritje Boga. Le s tem odkritjem zmore stopiti na pot odpuščanja, ki edino osvobaja, omogoča ozdravljenje in korak v drugačno prihodnost. Pri tem ne govorimo o poceni in lahki spremembi; kakor je bilo zgoraj že rečeno, je cena našega odrešenja cena krvi. Bog nas vabi, da bi sprejeli njega oziroma njegova znamenja, da bi sebe sprejeli kot ljubljene in lahko stopili naprej, tudi če nismo dosegli razume- 
vanja pri storilcu. Le kot ljubljeni vnaprej in brezpogojno zmoremo odpuščati in ljubiti v naših odnosih.

\subsubsection{Božji načrt odrešenja presega človeški greh}

Pogledali smo svetopisemski okvir sprave med dvema stranema v zavezi. Sveto pismo pa postreže z mnogo zgledi preizkušenj človeških življenj in odnosov, v katerih se izkažeta človeška beda in greh, a še bolj božje delovanje za odrešenje človeka. Božji načrt ne odvzema človeške svobode, temveč zmore Bog vse to usmeriti k odrešenju. S tem ni mišljeno ne opravičevanje niti poudarjanje teologije žrtve, temveč zgolj poudarja, da Bog zmore znotraj ranjenih odnosov obrniti stvari na dobro; seveda s prvim pogojem, da so navzoča spoznanje greha, kesanje in odpuščanje. (Erzar 2019, 9-16)

V svetopisemskem okviru je mogoče najti kar nekaj zgodb, ki s prikazom tako ranjenih družinskih odnosov kakor tudi z možnostjo sprave predstavijo analogijo za razmišljanje o ranjenosti in možnosti sprave znotraj Cerkve. Posebno mesto ima tu Jožefova zgodba, ki ga bratje iz nevoščljivosti izročijo ne direktno v smrt, temveč prodajo v suženjstvo (1 Mz 37,28). Sprava z odpuščanjem in vzpostavitvijo družinskih odnosov se zgodi postopoma. Jožef brate, ki ga ne prepoznajo, postavi na preizkušnjo, ko jih ozmerja z vohuni in jih v dokaz njihove iskrenosti pošlje nazaj po Benjamina. Ob tem ne le da se jim zbudita spomin in občutek krivde zaradi preteklega hudobnega dejanja do brata Jožefa, temveč morajo izkusiti pomen izgube in vklenitve v verige brata Simeona $(42,9-24)$. Oče Jakob v besedni igri nevede pove resnico, da so bratje krivi za izgubo Jožefa in Simeona $(42,36)$, in šele po sili razmer in zagotovilu sinov, da najmlajšega Benjamina pripeljejo nazaj, dovoli, da s seboj vzamejo tudi njega na pot v Egipt $(43,11-14)$.

Jožef je ob ponovnem srečanju s svojimi brati in z najmlajšim bratom Benjaminom ganjen in se najprej skrivaj zjoče, nato pa z brati v veselju obeduje (43,30-34). Znova jih postavi na preizkušnjo, ko podtakne svojo čašo Benjaminu. Bratje poskušajo pokazati svojo nedolžnost s tem, da predlagajo smrt storilca, in ko je krivda odkrita pri Benjaminu, v znak spokornosti raztrgajo svoja oblačila in želijo postati Jožefovi hlapci (44,13-17). Šele ko Juda razodene vso zgodbo in je pripravljen svoje življenje zastaviti za Benjaminovo, se Jožef ponovno zlomi in se razodene bratom $(44,18-45,3)$. Ob spoznanju božjega načrta pokaže, da je bratom odpustil $(45,4-8)$, in zmore z njimi stopiti v pogovor $(45,45)$. Zdaj se družina lahko zopet sreča in zaživi v miru (prim. 45,28).

\subsubsection{Dar odpuščanja}

Sprava je proces soočenja dveh strani zaveze. Včasih se ne zgodi srečanje obeh strani, saj je vse preveč boleče. Morda ni spreobrnjenja in obojestranske sprave, temveč samo odpuščanje, ki vsaj ranjeni strani pomaga, da stopi v bolj svobodno življenje, kakor se zdi, da pričuje Daniel Pittet s svojo življenjsko zgodbo Odpustil sem vam (2017). Pri tem govorimo seveda o procesu in vstopanju v svet presežnega in božjega, v katerem človek najde moč za odpuščanje, ljubezen in življenje. 
O pomenu verske izkušnje in odpuščanja spregovorijo tudi psihologi kakor Collin Barnes in Ryan Brown (2010), za naše razmišljanje pa nam Sveto pismo samo daje lepo število odlomkov o ponujenem odpuščanju in o možnosti življenja novega občestva. Poleg že omenjene prilike o usmiljenem očetu (Lk 15,11-32) v Matejevem evangeliju najdemo Jezusov poduk Petru glede pomena in nujnosti odpuščanja za življenje nebeškega kraljestva (Mt 18,15-35). Bog je nedvomno prvi v usmiljenju in brezmejnem odpuščanju. Pri tem ni pomembna cenena ali lažna odpustitev dolgov, temveč je bistven proces, ki zahteva zavestno spoznanje, odločitev in dostopnost. Ta proces se zgodi v treh korakih:

- Soočenje z resnico: priznanje in prošnja za odpuščanje.

- Sprejetje odpuščanja: sprejeti in razumeti miselnost odpuščanja.

- Živeti odpuščanje: odpustiti tudi drugim.

$\checkmark$ priliki, s katero Jezus ponazori pomembnost odpuščanja, je $v$ tem oziru pomenljiv prvi služabnik, ki ne razume in zaprt v logiko dolgo ostaja ločen od kraljestva Očeta (Mt 18,35). Služabnik dolguje 10000 talentov, to pa pomeni dolg, ki ga ni mogoče povrniti. Vendar pa služabnik pade na tla, počasti Gospoda in prosi za potrpljenje, češ da bo dolg povrnil, in kralj se služabnika usmili $(18,26-27)$. Služabnikovo vztrajanje po vrnitvi dolga je dvoumno: ali je sploh resnično obžaloval, ali je dojel pomen odpuščanja? Takoj v naslednjem trenutku s svojim življenjem logike dolga pokaže, da je dvom o pristnosti prošnje in o sprejemanju odpuščanja povsem upravičen. Služabnik ni pripravljen odpustiti dolga 100 denarijev, kolikršen je povrnitveni dolg njegovega soslužabnika, ki ga prosi na enak način in z istimi besedami $(18,28-30)$.

Sprava in odpuščanje sta potrebna, vendar pri tem ne govorimo o ceneni, neiskreni izreki ali o brisanju spomina, temveč o prejemanju božjega daru (prim. 2 Kor 5,20-21), saj je življenje mogoče le v resnici, odgovornosti, odpuščanju in v ljubezni. Za življenje žrtve je pomembno, da odpusti in bolj svobodno zaživi. Vendar pa tudi skupnost Cerkve pri tem lahko pomaga tako, da v ravnanju ne slepomiši in z duhovniki storilci kriminalnih dejanj ne ravna naivno, kakor odločno poudarja zaslužni papež Benedikt XVI. v knjigi Luč sveta, ko pravi: pomembno je, da se zavzamemo za žrtve, preprečimo takšna dejanja s pravilno izbiro kandidatov in da so storilci kaznovani ter je izključena vsaka možnost, da bi ponovili dejanja, z izključitvijo možnosti za nadaljnji dostop do otrok $(2011,40)$. To seveda ni preprosto, kakor pravi Stephen Rossetti, vendar je treba iskati načine, da ne pride takšen človek v stik z mladoletniki brez nadzora. Treba je odkriti način supervizije, ne glede na to, ali je duhovnik odpuščen iz kleriškega stanu ali ne. (Rossetti 2012, 36-39) Treba je obsoditi greh, kriminalno dejanje, in zadati zdravilno kazen znotraj okvirov pravične sodbe (Slatinek 2019, 727-737). Še bolj pomembno je, odkriti načine zavarovanja najšibkejših pred katerokoli obliko zlorabe. Vendar ni dovolj zgolj razmišljanje o krivcu in o krivdi, če se ob tem ne skruši duh in spreobrne srce (Lk 13,1-5), saj more le čisto srce videti in gledati Boga (Mt 5,8).

Ob razmišljanju o skupnosti, ki se sooča z grehom, se moramo vnovič spomniti izkušnje božjega ljudstva, ki kljub rešitvi iz hiše suženjstva in kljub daru zaveze prek besed 
življenja (2 Mz 20,2-17) še vedno izbere malikovanje kot lažno podobo Boga rešitve $(32,1-4)$. Sodba o grehu Arona ali ljudstva $(32,21-22)$ ne more najti rešitve $v$ uničenju $(31,28)$. Sodba in rešenje lahko nastopata le po pravičniku, ki kakor Mojzes sebe zastavi za rešenje ljudstva (32,11-12), in po Bogu, ki vodi k svojemu dnevu odrešenja $(32,34)$.

Nedvomno sta za graditev občestva pomembna odpuščanje in sprava. Odločitev za ljubezen in odpuščanje ni samoumevna in prihaja kot dar in sad molitve. Le poslušanje, priznanje greha, želja po spreobrnjenju in odpuščanje so prvi pogoj za spravo v skupnosti. Le sprejetje odpuščanja in odrešenja, ki je božji dar, omogoča odpuščanje v skupnosti in resnično življenje v občestvu božje družine, Cerkve.

\section{Sklep}

V prispevku smo problematiko poskušali svetopisemsko in teološko ovrednotiti. Spregovoriti o tej tematiki se je pokazalo kot potrebno, a ne preprosto, saj vsak zgled prinaša svojo zgodbo, polno bolečine, krivde, sramu, strahu, jeze in obupa. Vse bolj postaja jasno, da rešitev ni v skrivanju, saj kri nedolžnega brata vpije k Bogu (prim. $1 \mathrm{Mz} \mathrm{4,10),} \mathrm{obenem} \mathrm{pa} \mathrm{brez} \mathrm{resnice} \mathrm{in} \mathrm{ljubezni,} \mathrm{ki} \mathrm{odstirata} \mathrm{ranjenost} \mathrm{žrtev,}$ storilcev in celotne skupnosti, ni spreobrnjenja in ozdravljenja. $V$ tem procesu odpuščanja je nujna prošnja za čisto srce, ki je izraz želje po globini, po resnici in po srečanju s samim seboj in s svojim Bogom. Le to omogoča rast k primerni svobodi za odgovorno življenje iz ljubezni. V globini srca se zavemo dragocenosti daru božjega življenja in krhkosti človeških posod (2 Kor 4,7). Spričo te krhkosti je celotna skupnost povabljena k rasti. Rast in krhkost skupnosti se kažeta tudi v njenih duhovnikih, zato velja poudariti pomen celostne formacije prihodnjih duhovnikov, pri tem pa je sta pomembna tako priprava na duhovništvo kakor tudi vseživljenjsko spremljanje v njihovem pastoralnem prizadevanju, saj le pastirji, ljudje in duhovniki po Kristusovem zgledu, vodijo k polnemu življenju z Bogom.

\section{Reference}

Barnes, Collin, in Ryan Brown. 2010. A value-congruent bias in the forgiveness forecasts of religious people. Psychology of religion and spirituality 2, no. 1:17-29.

Benedikt XVI. 2011. Luč sveta: Papež, Cerkev in znamenja časa. Pogovor s Petrom Seewaldom. Ljubljana: Družina.

Bovati, Pietro. 2005. Ristabilire la giustizia: Procedure, vocabolario, orientamenti. Analecta Biblica 110. Roma: Pontificio Istituto Biblico.

Carola, Joseph, Mark Rotsaert, Michelina Tenace in Miguel H. Yáñez. 2012. Drinking at the springs of healing and renewal: towards a deeper theological reflection on the problem of sexual abuse in the church. V: Charles J.
Scicluna, Hans Zollner in David J. Ayotte, eds. Toward healing and renewal: The 2012 symposium on the sexual abuse of minors held at the Pontifical Gregorian University, 121-137. New York: Paulist Press.

Erzar, Tomaž. 2019. Trije povezovalni momenti v terapevtskem procesu odpuščanja in krščanski model odpuščanja. Bogloslovni vestnik 79, št. 1:9-16.

Keenan, Marie. 2012. Child sexual abuse and the Catholic Church: Gender, power, and organizational culture. Kindle edition. New York: Oxford University Press 
Kongregacija za nauk vere. 2020. Vademecum: On certain points of procedure in treating cases of sexual abuse of minors committed by clerics. Holy See. http://www.vatican.va/roman_curia/ congregations/cfaith/documents/rc_con_cfaith_doc_20200716_vademecum-casi-abuso_ en.html (pridobljeno 26. 9. 2020).

Pittet, Daniel. 2017. Odpustil sem vam: Resnična zgodba o ranjenem otroštvu. Ljubljana: Družina.

Rossetti, Stephen J. 2012. Learning from our mistakes: responding effectively to child sexual abusers. V: Charles J. Scicluna, Hans Zollner in David J. Ayotte, ur. Toward healing and renewal: The 2012 symposium on the sexual abuse of minors held at the Pontifical Gregorian University, 29-46. New York: Paulist Press.
Slatinek, Stanislav. 2019. Pravica do pravične sodne odločitve ob sumu spolne zlorabe mladoletne osebe. Bogoslovni vestnik 79, št. 3:727-737. 